\title{
Plant-Parasitic Nematodes on Sugarcane in Florida ${ }^{1}$
}

William T. Crow ${ }^{2}$

\section{Causal Agents}

Plant-parasitic nematodes are microscopic roundworms that feed on and damage plants. Ectoparasitic nematodes live and reproduce in soil and feed on roots from outside. Endoparasitic nematodes enter into the roots to feed and reproduce. Sting nematode (Belonolaimus longicaudatus), an ectoparasite, is the most damaging nematode to sugarcane in Florida. Stubby-root (Trichodorus and Paratrichodorus spp,), ring (Criconemoides and related genera), and stunt (Tylenchorhynchus and Quinisulcius) nematodes are other ectoparasites that may damage sugarcane and are common in Florida. Endoparasites that may damage sugarcane in Florida are lesion (Pratylenchus zeae), lance (Hoplolaimus spp.), and root-knot (Meloidogyne spp.) nematodes. Most species of plant-parasitic nematodes favor sandy conditions and are rarely a problem on muck soils. However, on sugarcane grown in sandy areas may suffer dramatic yield losses from nematodes.

\section{Symptoms}

Damage caused by plant-parasitic nematodes is most severe on sandy soil, and rarely occurs on muck.
Visually, crop damage usually occurs in non-uniform patches within a field, but occasionally widespread damage is evident (Figure 1). Stunting of planted cane and poor stand may become evident soon after planting. Because roots that are damaged by nematodes do not function properly, wilting may occur in nematode-infested sites more rapidly than in non-infested sites. Nutrient deficiency symptoms, particularly yellowing or chlorosis, may occur even when nutrients are present at sufficient levels in soil. Damage to cane may increase on successive ratoon crops (Figure 1).

Sugarcane roots that are damaged by ectoparasitic nematodes may appear stubby, coarse, and discolored, and lack feeder roots (Figure 2). The endoparasitic lesion and lance nematodes cause reddish lesions (Figure 3), and in severe infestations cause discoloration and rotting of the root system (Figure 4). Root-knot nematodes may cause swellings or galls on roots (Figures 5, 6), but on sugarcane these galls are not as large as on vegetable crops. It should be noted that in the field it is common for multiple nematode genera to cause damage in the same field. Therefore, a mixture of root symptoms may occur together on the same plants.

1. This document is ENY-053, one of a series of the Entomology \& Nematology Department, Florida Cooperative Extension Service, Institute of Food and Agricultural Sciences, University of Florida. First published: September 2004. This publication is also a part of the Florida Sugarcane Handbook, an electronic publication of the Agronomy Department. For more information you may contact the editor of the Sugarcane Handbook, R. A. Gilbert (ragilbert@gnv.ifas.ufl.edu). Please visit the EDIS Web site at http://edis.ifas.ufl.edu.

2. William T. Crow, assistant professor, Entomology \& Nematology Department, Cooperative Extension Service, Institute of Food and Agricultural Sciences, University of Florida, Gainesville, 32611.

The Institute of Food and Agricultural Sciences (IFAS) is an Equal Employment Opportunity - Affirmative Action Employer authorized to provide research, educational information and other services only to individuals and institutions that function without regard to race, creed, color, religion, age, disability, sex, sexual orientation, marital status, national origin, political opinions or affiliations. For information on obtaining other extension publications, contact your county Cooperative Extension Service office. Florida Cooperative Extension Service / Institute of Food and Agricultural Sciences / University of Florida / Larry R. Arrington, Interim Dean 


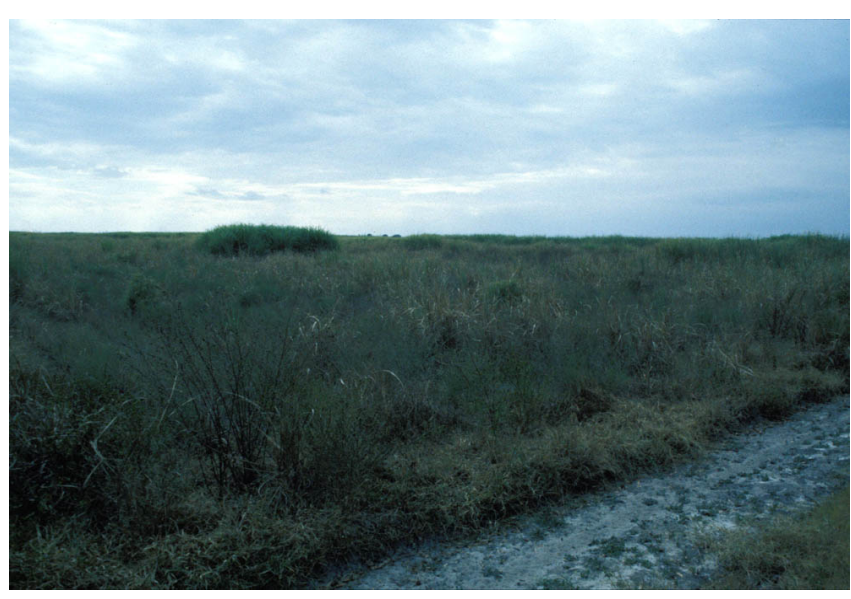

Figure 1. 1-year old ratoon cane grown on sandy soil heavily infested with sting nematode. The sugarcane stand is sparse, stunted, and weeds predominate. Credits: W. T. Crow, University of Florida

\section{Detection}

The University of Florida provides a nematode diagnostic service for detection and diagnosis of nematode problems on sugarcane and other crops. There is a $\$ 12$ fee for each sample submitted. Some private labs also can perform nematode diagnosis. In areas of damaged cane where nematodes are suspect, collect soil and roots from between 12 and 20 symptomatic plants in a given field. Sampled plants should be showing symptoms, but should not be dead. Dig up the plants to be sampled and collect a handful of roots and a handful of soil from the root ball of each plant. Mix the soil and roots from the 12 to 20 plants to make a single sample for each field. Then put about 2 handfuls of the mixed roots along with a pint of the mixed soil into a plastic bag and seal it up. For samples taken before planting, collect a handful of soil from about 12 inches deep from 12 to 20 areas of the field, mix, and then put about a pint of the soil into a plastic bag and seal. Make sure that you keep the bags with soil and roots in a cool area and out of the sun until the sample can be submitted to the lab. Information for submitting samples to the University of Florida Nematode Assay Laboratory can be obtained on-line at http://edis.ifas.ufl.edu/SR011 or by calling (352) 392-1994.
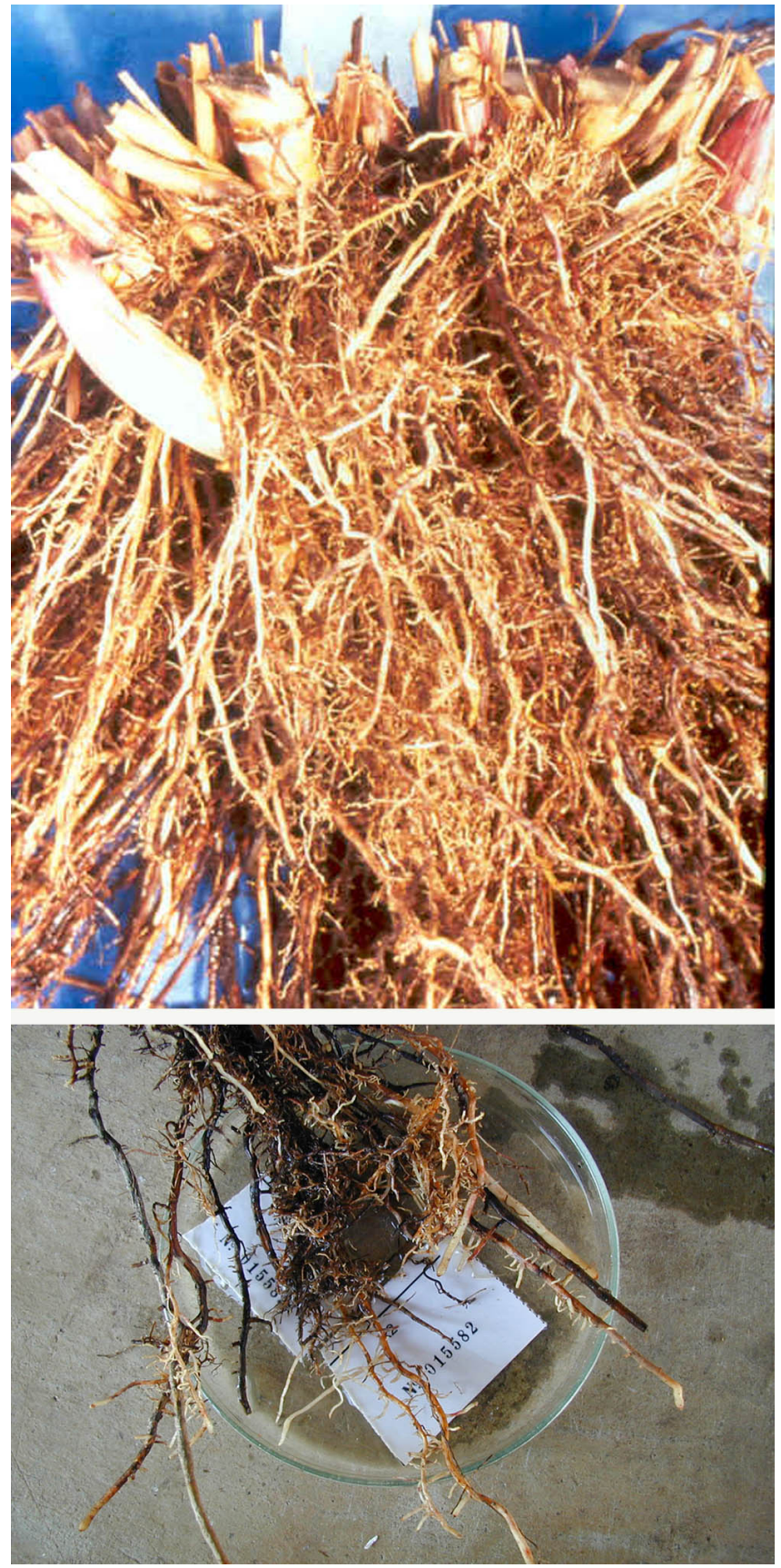

Figure 2. (top) Healthy sugarcane roots and (bottom) roots damaged by ectoparasitic nematodes . Credits: (top) G. Stirling, Biological Crop Protection, Australia; (bottom) S. Berry, South African Sugar Association

\section{Management}

\section{Chemicals}

A few nematicides are labeled for use on sugarcane. They can be cost effective, especially on sandy soils. However, at present nematicides are only labeled as preplant treatments and cannot be used on ratoon cane. Plant-parasitic nematode numbers can 


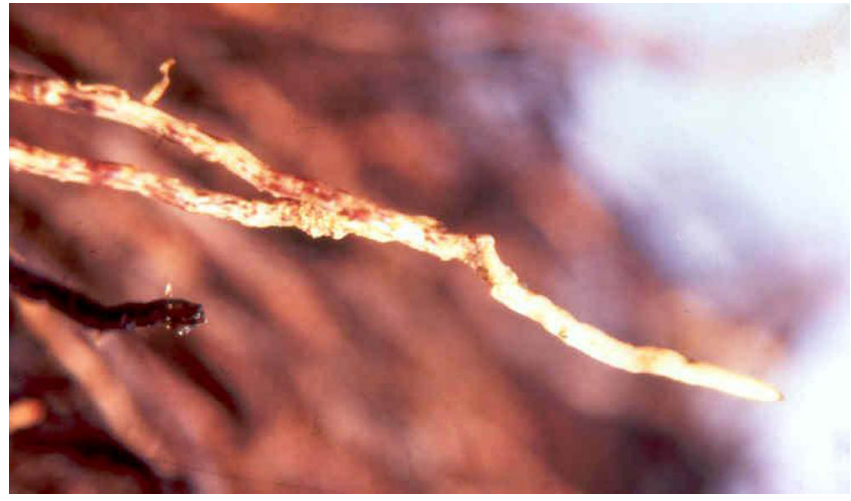

Figure 3. Sugarcane roots infested with lesion nematodes exhibit reddish lesions. Credits: G. Stirling, Biological Crop Protection, Australia

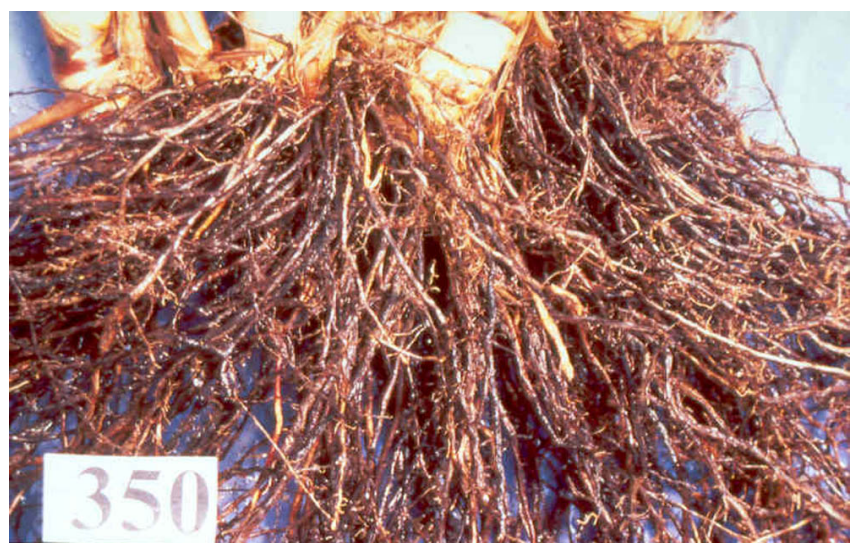

Figure 4. Sugarcane roots heavily infested with lesion nematodes are discolored and rotting. Credits: G. Stirling, Biological Crop Protection, Australia

build up rapidly throughout the course of a year. Therefore, while nematicide use in infested areas may greatly improve the yield of the first harvest, there may not be any yield benefits on sequential harvests.

Mocap (ethoprop) products are commonly used on sugarcane for wireworm control and are also labeled for control of plant-parasitic nematodes. Granular formulations are usually banded directly on seed pieces before closing the rows.

Telone (1,3-dichloropropene) products are excellent nematicides, especially in sandy soil. Telone products also are labeled for control of wireworms. They are fumigant products that are injected into soil prior to planting. Formulations containing chloropicrin (Telone C-17, Telone C-35), while more expensive than the formulation without chloropicrin (Telone II), have added fungicidal effects. In Florida, Telone products are very effective

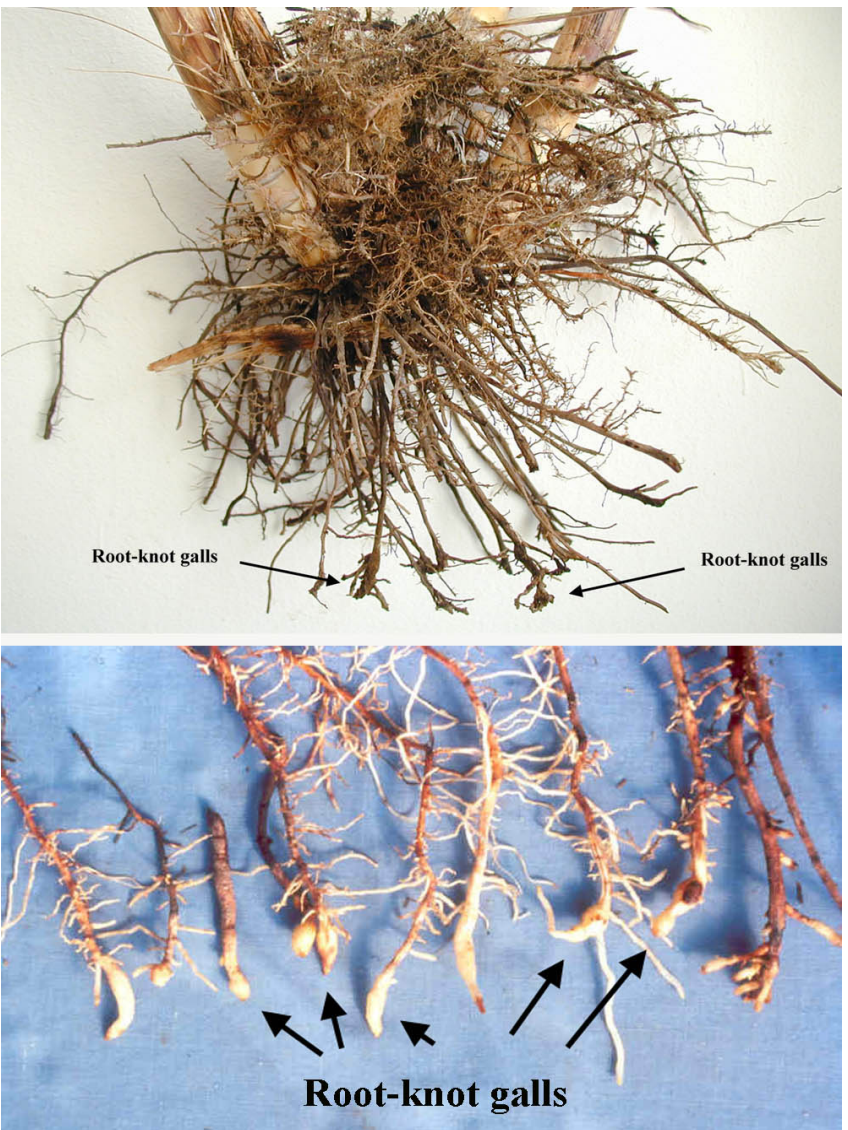

Figure 5. Sugarcane roots infested with root-knot nematodes exhibit galls or swellings. Galls may be more pronounced near root ends. Credits: (top) S. Berry, South African Sugar Association; (bottom) G. Stirling, Biological Crop Protection, Australia

for all nematodes. However, stubby-root nematode populations are known to increase rapidly following fumigation with Telone.

\section{Fallow}

Most of the plant-parasitic nematode species that feed on sugarcane in Florida also have many weed hosts. Therefore, unless weeds are eliminated, fallow will probably be of little benefit for nematode management on sugarcane.

\section{Flooding}

Plant-parasitic nematodes are affected by flooded conditions. In certain areas of Florida flooding may be used as a nematode management tactic for sugarcane. For best results, the area needs to be 


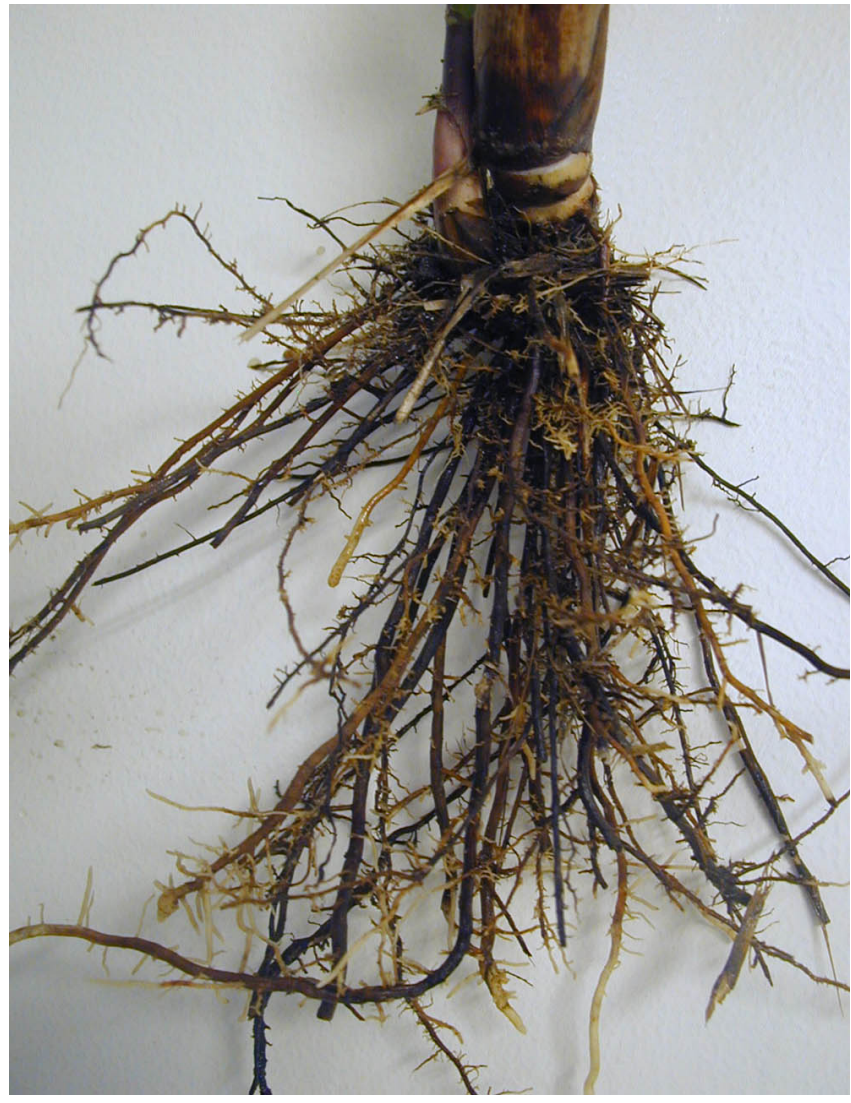

Figure 6. Sugarcane roots being damaged by multiple nematode species. Credits: S. Berry, South African Sugar Association

flooded for a 4 week period, then drained and left dry for 2 weeks, and then flooded once again for 4 weeks.

\section{Rotation}

Rotation with wetland rice can reduce populations of plant-parasitic nematodes. Many of the nematodes that feed on sugarcane are able to feed on rice under dry conditions. However, because rice is normally grown in standing water, most of the nematodes are killed by the flooded conditions.

If vegetables are to be planted following sugarcane, it is important that nematode assays be conducted before planting the vegetables. Often, root-knot, sting, or other nematodes may build up to large numbers on the sugarcane and then cause extensive damage to the vegetable crop.

\section{Amending Soil}

Filtercake or "mud" is the sediment left over following clarifying of sugarcane juice. Filtercake can be added as an amendment to sandy areas to reduce nematode damage. In experiments, filtercake amendment has been shown to reduce populations of plant-parasitic nematodes on sugarcane. Also, by adding organic matter to sandy soil, filtercake can improve plant tolerance and make nematode damage less severe. 